\title{
研究報告
}

\section{Characterization and Identification of Tetragenococcus halophilus and Tetragenococcus muriaticus Strains from Fish Sauce (Nam-pla)}

\author{
Jaruwan Thongsanit ${ }^{*}$, Somboon Tanasupawat ${ }^{1 \dagger}$, Suwimon Keeratipibul ${ }^{2}$, \\ and Suchada JaTIKAVANICH \\ Department of Microbiology, Faculty of Science, \\ ${ }^{i}$ Department of Microbiology, Faculty of Pharmaceutical Sciences \\ ${ }^{2}$ Department of Food Technology, Faculty of Science, \\ Chulalongkorn University, Bangkok 10330, Thailand
}

\begin{abstract}
Eighty strains of homofermentative tetrad-forming lactic acid bacteria were isolated from fish sauce fermentation in Thailand. These bacteria were divided into three groups based on the phenotypic and chemotaxonomic characteristics including DNA relatedness. Forty strains (Group I) showed high degrees (70.0\% to 109.1\%) DNA-DNA homology with Tetragenococcus halophilus ATCC $33315^{\prime \prime}$. They were identified as T. halophilus. Thirty-eight strains (Group II) showed high degrees (70.9\% to 105.6\%) of DNA-DNA homology with Tetragenococcus muriaticus JCM $10006^{2}$. They were identified as T. muriaticus. Two strains (Group III) showed low degrees (3.7\% to $16.3 \%$ ) of DNA-DNA homology with T. halophilus ATCC 33315, T. muriaticus JCM 10006, and Aerococcus viridans TISTR $393^{\prime \prime}$. Then they were left unidentified. Group I and Group II strains are halophilic which grew in $25 \% \mathrm{NaCl}$. All the strains tested produced L-lactic acid and contained cellular fatty acids with C18:1 as the major component. Some of the selected strains produced histamine ranging from 0.04 to $52.29 \mathrm{mg} / 100 \mathrm{ml}$. The differentiation of Tetragenococcus strains is discussed.
\end{abstract}

Key Words : Fish sauce; halophilic; lactic acid bacteria; Tetragenococcus halophilus; Tetragenococcus muriaticus

The moderately halophilic lactic acid bacteria, $T$. halophilus, formerly known as "Pediococcus halophilus" has been reported and described ${ }^{1-9)}$. This bacterium was reclassified in the genus Tetragenococcus based on $16 \mathrm{~S}$ rRNA studies ${ }^{(1)}$. Recently, the existence of a second species, T. muriaticus, has been proposed ${ }^{11)}$, and the differentiation of these Tetragenococcus strains was described by Kobayashi et $a l .{ }^{12)}$. Fish sauce is a clear brown liquid traditionally produced and widely used in Southeast Asia and to some extent in other parts of the world ${ }^{(3.14)}$. This product contains high concentrations of $\mathrm{NaCl}$ and it

${ }^{\dagger}$ To whom correspondence should be addressed. Phone :

Fax :

E-mail : tsomboon@chula.ac.th was in this that "Pediococcus halophilus" was found ${ }^{6,15)}$. T. halophilus and $T$. muriaticus strains have been found in Japanese squid liver sauce and puffer fish ovaries ${ }^{11,12)}$, but their isolation from fish sauce (nam-pla) in Thailand has not been reported. This work deals with the identification of tetradforming cocci from fish sauce fermentation in Thailand based on phenotypic and chemotaxonomic characteristics including the results of photobiotin labeling DNA-DNA hybridization siudies.

Materials and Methods

Isolation method. The fish sauce samples were obtained from three factories in Samutprakarn, Samutsongkhram and Chonburi Provinces, and lactic acid bacteria were isolated by a pour plate technique 
using MRS agar ${ }^{(i)}$ with $5 \% \mathrm{NaCl}$ incubating at $30^{\circ} \mathrm{C}$ for 3-5 days.

Bacterial cultures. Eighty isolates and each of the strains of Tetragenococcus halophilus ATCC 33315 (American Type Culture Collection, Manassas, VA, USA), Tetragenococcus muriaticus JCM $10006^{11}$ (Japan Collection of Microorganisms, Saitama, Japan) and Aerococcus viridans TISTR 393' (Thailand Institute of Scientific and Technological Research, Bangkok, Thailand) were used in this study. All tests were carried out by incubating the cultures at $30^{\circ} \mathrm{C}$, except for the study on the effects of temperature. The strain number PM, PW, PB, PS or P indicated the strain from Samutprakarn; $\mathrm{K}$ from Samutsongkhram and $\mathrm{C}$ from Chonburi while the number $0,1,2,3, \cdots 18$ (month) and the number 30 and 60 (day) of strain number indicated the period of fermentation of batches from which they were isolated.

Morphological and cultural characteristics. Cell form, cell size, cell arrangement, and colonial appearance were examined on the cell grown on MRS agar with $5 \% \mathrm{NaCl}$ incubated for 5 days. Hucker-Conn modification ${ }^{17}$ was used for gram stain. Spore formation was examined in gram-stained specimens. Motility was detected by the appearance of stab cultures in soft agar ${ }^{18}$.

Biochemical and physiological characteristics. The following tests were carried out: activities of catalase with hematin in the medium and of oxidase, nitrate reduction, hydrogen sulfide formation, and the hydrolysis of arginine, casein, starch, gelatin and tributyrin. In addition, the oxidation-fermentation test and the Methyl red-Voges-Proskauer reaction were performed, as previously reported ${ }^{19-21)}$. The effect of temperature $\left(40,50^{\circ} \mathrm{C}\right)$ and different starting $\mathrm{pHs}(4.2,5.0,6.5,8.0$, and 9.0) were determined in MRS with $5 \% \mathrm{NaCl}$ while the different concentrations of $\mathrm{NaCl}(0,10,15,20$, and $25 \%)$ were tested by using MRS broth as basal medium. Acid formation from carbohydrates was determined in medium supplemented with $5 \% \mathrm{NaCl}$ as reported previously ${ }^{21}$. The tested strains were cultivated in histidine containing medium with $10 \% \mathrm{NaCl}$ and the supernatant was analyzed for histamine by the AOAC method ${ }^{22)}$.

Isomer of lactic acid. The tested strains were cultivated in GYPB broth with $5 \% \mathrm{NaCl}$ for 5 days ${ }^{21)}$. Lactic acid was extracted from the supernatant of the fermentation broth with ether and was analyzed by the enzymatic method reported by Okada et al. ${ }^{23)}$.

Cellular fatty acid composition. Methyl esters of fatty acids were prepared using a 5\% methanolic hydrochloric acid solution from dried cells $(40 \mathrm{mg}$ ), which were cultivated in MRS broth with $5 \% \mathrm{NaCl}$ as described by Ikemoto et al. ${ }^{24)}$. The samples were analysed by gas-liquid chromatography.

DNA-DNA hybridization. DNAs were isolated from cells grown in MRS broth with $5-10 \% \mathrm{NaCl}$ after incubating for 1-2 days and were purified by the method of Saito and Miura ${ }^{25)}$. For strains with difficult in isolation of DNA, the medium was supplemented with $0.5 \%$ glycine $^{2 i)}$. Photobiotin labeling DNA-DNA homologies were carried out in $2 x$ SSC (saline trisodium citrate) and $50 \%$ formamide solution at $40^{\circ} \mathrm{C}$ for $12 \mathrm{~h}$ and detected by the colorimetric method ${ }^{27,28)}$.

\section{Results and Discussion}

A total of 80 strains of tetrad-forming lactic acid bacteria isolated from multiple batches of fish sauce fermentation at 3 factories in Thailand were divided into three groups based on phenotypic and chemotaxonomic characteristics including DNA relatedness. Group I and Group II strains are halophilic and were belong to the genus Tetragenococcus while Group III strains are similar to the genus Pediococcus and Aerococcus as shown in Tables 1 to $4^{1,29-32)}$. All the strains were gram-positive cocci $(0.6$ to $1.0 \mu \mathrm{m}$ in diameter) and they appeared singly, in pairs, and in tetrads. Cells were nonmotile and nonsporing. Colonies on MRS agar plate were circular, low convex with entire margin, and nonpigmented. They were homofermentative and microaerophilic. All strains showed negative reactions to oxidase Voges-Proskauer reaction hydrolysis of starch, gelatin and tributyrin hydrogen sulfide formation and nitrate reduction. They produced catalase in the medium containing hematin and showed Methyl red reaction. Most of the strains in Group I and II hydrolyzed arginine and Group II strains hydrolysed casein. All strains tested grew at $\mathrm{pH}$ levels of 6.5 and 9.0 , but not at $\mathrm{pH} 4.2$, and at $40^{\circ} \mathrm{C}$, but not at $50^{\circ} \mathrm{C}$. Most of the Group II strains did not grow in $0 \% \mathrm{NaCl}$. All produced acid from $\mathrm{D}$ glucose and $\mathrm{D}$-fructose and variable reactions were shown in Table 1. The tested strains produced histamine ranging from 0.04 to $52.29 \mathrm{mg} / 100 \mathrm{ml}$ (Table 2). 
All tested strains in Group I produced low concentration of histamine while the most of the strains in Group II produced high concentrations. Histamine production was found to be variable in the strains of Group II (Table 2).

The strains in Group I (PM0-8, PM0-10, P7-23, P727, K4-2, K2-32, K5-51, K6-35, C1-5, and C1-14); Group II (PW0-8, P7-37, K1-31, K3-26, P7-18, and C21; and Group III ( $\mathrm{C} 0-1)$ produced $\mathbf{L}+\mathbf{D L}$ or $\mathbf{L}$-lactic acid as the major product from glucose as reported for T. halophilus ATCC $33315^{\mathrm{T}}$ and T. muriaticus JCM $10006^{111122)}$. The tested strains contained cellular fatty acid of $\mathrm{C} 18: 1$ as the major component. The straight chain acids of C14:0, C14:1, C16:0, C16:1, C18:0, C20:1, and Cy 19 cyclopropane acids were also found as is shown in Table 3. The strains in Group I (PM0-8, P7-23, K2-44, K4-16) and Group II (P7-18, K131, K3-26, K5-37, K18-1, C2-1) showed the same fatty acid profiles. Because fatty acids were esterified by refluxing with $\mathrm{HCl} / \mathrm{Methanol}$, the amount of $\mathrm{Cy} 19$ cyclopropane acids was not as high as reported for up. "P. halophilus" by Ushida and Mogi'33) However this result is consistent with the fatty acid profiles described by Satorni et. ${ }^{11}$. Although the C18:1 content of Group I and Group II strains was slightly different, this characteristic was not significant enough for their differentiation. Group III strains ( $\mathrm{C} 0-1, \mathrm{C} 0$ 2) had no Cy 19 cyclopropane acids and contained the same fatty acid profiles as reported for Aerococcus viridans ${ }^{3)}$.

The DNA relatedness as shown in Table 4 indicated that forty strains in Group I (PM0-8, PM0-10, PW07, PW0-13, PB30-1, PB30-3, PS60-2, PS60-6, PB60-2, P3-1, P3-2, P3-3, P3-4, P3-5, P7-2, P7-7, P7-23, P7-26, $\mathrm{P} 7-27, \mathrm{~K} 0-2$, K2-32, K2-34, K2-44, K4-2, K4-16, K4-40, K4-47, K5-51, K6-32, K6-35, C1-1, C1-2, C1-5, C1-6, C18, C1-9, C1-12, C1-14, C1-17, C1-19) showed high degrees $(70.0 \%$ to $109.1 \%)$ of DNA-DNA homology with T. halophilus ATCC $33315^{\prime}$. They grew in MRS medium with no $\mathrm{NaCl}$ and fermented a variety of carbohydrates. All grew in $25 \% \mathrm{NaCl}$ (Table 1). They were identified as T. halophilus ${ }^{11,31)}$.

Thirty-eight strains in Group II (PW0-8, PW0-15, P4-3, P4-5, P4-6, P5-1, P5-2, P5-3, P6-1, P6-3, P6-4, P718, P7-37, K1-10, K1-31, K1-35, K1-46, K2-9, K2-17, K229, K3-6, K3-26, K3-29, K3-40, K3-46, К5-37, K5-55, K6-29, K6-50, K8-1, K8-5, K8-13, K9-1, K9-2, K18-1,
K18-6, K18-12, C2-1) showed high degrees (70.9\% to $105.6 \%)$ of DNA-DNA homology with T. muriaticus JCM $10006^{\top}$ (Table 4). Few of them grew in MRS with no $\mathrm{NaCl}$, but all did in $25 \% \mathrm{NaCl}$. Most of them did not ferment as many carbohydrates as Group I strains (Table 1). They were identified as $T$. muriaticus $^{11,31)}$.

Two strains in Group III (C0-1, C0-2.) showed low degrees (3.7\% to $16.3 \%$ ) of DNA-DNA homology with T. halophilus ATCC $33315^{\mathrm{r}}$, T. muriaticus JCM $10006^{\mathrm{T}}$, and $A$. viridans TISTR $393^{\mathrm{r}}$ (Table 4). They did not grow in $20 \% \mathrm{NaCl}$. Their charactristics are similar to Pediococcus and Aerococcus ${ }^{30,22)}$. Further studies on their 16S r RNA sequences would have required proposing a new spcecies, and were therefore left unidentified.

$T$. halophilus strains have preiously been reported $^{1.9)}$. A total of 11 strains of T. muriaticus were isolated from fermented squid liver sauce and proposed as a new species ${ }^{11)}$. Recently, Kobayashi et al. ${ }^{12)}$ described the differentiation of $T$. halophilus and $T$. muriaticus strains from fermented puffer fish ovaries based on their ability to grow in medium not supplemented with $\mathrm{NaCl}$ and the fermentation of $\mathrm{L}$ arabinose, sucrose and D-mannitol including genotypical typing of the 16S rRNA gene. These two species have been classified based on strains from soy sauce, fermented squid liver sauce and fermented puffer fish ovaries ${ }^{5,11,12)}$. In this study, we found many isolates from fish sauce (narn-plai). These isolates displayed characteristics which varied widely from one another, and also varied from characteristics of the type strains shown in Table 1. Their growth in MRS broth with no $\mathrm{NaCl}$ as mentioned by Satomi et $a l .{ }^{11}$ and Kobayashi et $a l^{12}$. appear useful for separating T. halophilus and T. muriaticus strains. The hydrolysis of casein and acid from sucrose supported their differentiation. Arginine hydrolysis, acids from $\mathrm{L}$-arabinose and $\mathrm{D}$-mannitol, and histamine production are not sufficient to differentiate these two species according to Satomi et al." ${ }^{11}$ and Kobayashi et al. ${ }^{12)}$ Photobiotin labeling DNA-DNA hybridization is simple and useful for the identification of these two species.

T. halophilus and T. muriaticus strains are widely distributed in many batches of fish sauce fermentation in Thailand. They fermented many carbohy- 
Table 1. Characteristics Tetragenococcus strains

\begin{tabular}{|c|c|c|c|c|c|}
\hline Characteristics & $\begin{array}{l}\text { T. halophilus } \\
\text { ATCC } 33315^{\prime \prime}\end{array}$ & $\begin{array}{l}\text { T. muriaticus } \\
\text { JCM } 10006^{\mathrm{T}}\end{array}$ & $\begin{array}{l}\text { Group I } \\
\quad(40)\end{array}$ & $\begin{array}{c}\text { Group II } \\
(38)\end{array}$ & $\begin{array}{c}\text { Group III } \\
\text { (2) }\end{array}$ \\
\hline Cell shape & & & Cocci & & \\
\hline Hydrolysis of arginine & + & - & $+(-1)$ & $+(-8)$ & + \\
\hline Hydrolysis of casein & - & + & $-(+3)$ & $+(-7)$ & + \\
\hline Growth at $40^{\circ} \mathrm{C}$ & - & + & + & + & + \\
\hline Growth at $\mathrm{pH} 5.0$ & + & + & $+(-17)$ & $+(-17)$ & + \\
\hline 6.5 & + & + & + & + & + \\
\hline 9.0 & + & + & + & + & + \\
\hline Growth in $0 \% \mathrm{NaCl}$ & + & - & + & $+(+2)$ & + \\
\hline $15 \% \mathrm{NaCl}$ & + & + & + & + & + \\
\hline $20 \% \mathrm{NaCl}$ & + & + & + & + & - \\
\hline $25 \% \quad \mathrm{NaCl}$ & + & + & + & + & - \\
\hline \multicolumn{6}{|l|}{ Acid from: } \\
\hline Amygdalin & + & + & $+(-1)$ & $+(-9)$ & + \\
\hline $\mathbf{L}$-Arabinose & - & + & $+(-8)$ & $+(-12)$ & + \\
\hline D-Cellobiose & + & - & $+(-1)$ & $+(-15)$ & + \\
\hline Dextrin & - & + & $+(-17)$ & $-(+15)$ & + \\
\hline Esculin & + & + & $+(-4)$ & $+(-7)$ & + \\
\hline D-Galactose & + & + & $+(-4)$ & $+(-11)$ & + \\
\hline Glycerol & + & - & $+(-16)$ & $-(+16)$ & - \\
\hline Lactose & - & - & $-(+17)$ & $-(+3)$ & + \\
\hline Maltose & + & + & $+(-3)$ & $+(-19)$ & + \\
\hline D-Mannitol & - & + & $+(-15)$ & $+(-7)$ & + \\
\hline D-Mannose & + & + & $+(-1)$ & $+(-3)$ & + \\
\hline D-Melibiose & - & + & $+(-15)$ & $-(+13)$ & - \\
\hline D-Melezitose & + & - & $+(-14)$ & $-(+3)$ & - \\
\hline$\alpha$-Methyl-D-glucoside & + & + & $+(-8)$ & $-(+8)$ & $+(-1)$ \\
\hline Raffinose & - & - & $-(+12)$ & $-(+2)$ & - \\
\hline Rhamnose & - & + & $+(-20)$ & $-(+3)$ & - \\
\hline D-Ribose & + & + & + & $+(-10)$ & + \\
\hline Salicin & + & + & $+(-5)$ & $+(-9)$ & + \\
\hline D-Sorbitol & - & + & $+(-10)$ & $-(+18)$ & - \\
\hline L-Sorbose & + & + & $+(-9)$ & $-(+18)$ & $+(-1)$ \\
\hline Sucrose & + & - & $+(-9)$ & $-(+5)$ & + \\
\hline D-Trehalose & + & + & $+(-8)$ & $+(-17)$ & + \\
\hline $\mathrm{D}$-Xylose & + & + & + & $+(-2)$ & + \\
\hline
\end{tabular}

+ , positive reaction; - negative reaction; Numbers in parentheses indicate the number of strains showing the reaction. 
drates and showed various characteristics. In Thailand, there are many kinds of fermented fish with high concentrations of $\mathrm{NaCl}$ such as pla-ra, plachom, kung-chom, shrimp paste, tai-pla, etc ${ }^{(5)}$. For further investigation, would be interesting to compare their characteristics with the tetracoccal isolates from other fermented products.

\section{Acknowledgements}

We thank the director and the staffs of fish sauce factories in Samutprakarn, Samutsongkhram and
Chonburi for providing the samples; Dr. Phantip Suwansakornkul, Department of Fisheries, Ministry of Agriculture and Cooperative for advising the histamine analysis; and Dr.Ken-ichiro Suzuki, Japan Collection of Microorganisms, Saitama, Japan for supplying the type strain.

\section{References}

1) Nakagawa, A. and K. Kitahara.: Taxonomic studies on the genus Pediococcus. J. Gen. Appl. Microbiol., 5, 95-126 (1959).

2) Coster, E. and White, H. R.: Further studies of the genus Pediococcus. J. Gen. Microbiol., 37, 15-31

Table 2. Histamine production of Tetragenococcus strains

\begin{tabular}{|c|c|c|c|}
\hline Strain & $\begin{array}{l}\text { Histamine } \\
(\mathrm{mg} / 100 \mathrm{ml})\end{array}$ & Strain & $\begin{array}{l}\text { Histamine } \\
(\mathrm{mg} / 100 \mathrm{ml})\end{array}$ \\
\hline Group I & & Group II & \\
\hline $\mathrm{PM}-8$ & 0.42 & K3-6 & 52.29 \\
\hline $\mathrm{PW}-7$ & 2.32 & K3-40 & 23.99 \\
\hline PM-10 & 0.05 & K3-46 & $30: 52$ \\
\hline PM-13 & 0.15 & K5-37 & 0.04 \\
\hline P7-23 & 0.70 & K5-55 & 26.65 \\
\hline P7-27 & 0.45 & $\mathrm{~K} 6-29$ & 43.39 \\
\hline K2-34 & 0.19 & K8-1 & 17.79 \\
\hline $\mathrm{K} 2-44$ & 1.89 & K8-5 & 24.87 \\
\hline $\mathrm{K} 4-2$ & 3.46 & K8-13 & 8.37 \\
\hline $\mathrm{K} 4-16$ & 4.46 & K9-1 & 32.39 \\
\hline $\mathrm{K} 4-40$ & 0.10 & $\mathrm{~K} 9-2$ & 50.24 \\
\hline K6-32 & 3.27 & $\mathrm{~K} 18-1$ & 17.79 \\
\hline C1-6 & 0.12 & K18-6 & 39.87 \\
\hline Group II & & K18-12 & 15.29 \\
\hline PW-8 & 44.22 & Group III & \\
\hline PW-15 & 13.11 & $\mathrm{C} 0-1$ & 42.81 \\
\hline P7-18 & 44.00 & $\mathrm{C} 0-2$ & 22.87 \\
\hline P7-37 & 0.20 & T. halophilus ATCC $33315^{\mathrm{T}}$ & 0.05 \\
\hline K1-10 & 0.10 & T. muriaticus JCM $10006^{\mathrm{T}}$ & 44.03 \\
\hline $\mathrm{K} 1-31$ & 29.27 & & \\
\hline K1-46 & 6.82 & & \\
\hline $\mathrm{K} 1-35$ & 1.14 & & \\
\hline K2-9 & 0.12 & & \\
\hline $\mathrm{K} 2-29$ & 29.16 & & \\
\hline K3-26 & 38.84 & & \\
\hline
\end{tabular}


(1964).

3) Whittenbury, R.: $\Lambda$ study of some pediococci and their relationship to Aerococcus viridans and the enterococci. J. Gen. Microbiol., 40, 97-106 (1965).

4) Sakaguchi, K.and Mori, H.: Comparative study on Pediococcus halophilus $P$. soyae, $P$. homari, $P$. urinae-equi and related species. J. Gen. Appl. Microbiol., 15, 159-167 (1969).
5) Uchida, K.: Multiplicity in soy pediococci carbohydrate fermentation and its application for analysis of their flora. J. Gen. Appl. Microbiol., 28, 215-223 (1982).

6) Tanasupawat, S. and Daengsubha, W.: Pediococcus species and related bacteria found in fermented foods and related materials in Thailand. $J$. Gen. Appl. Microbiol., 29, 487-506 (1983).

Table 3. Cellular fatty acid composition (\%) of Tetragenococcus strains

\begin{tabular}{ccccccccccc}
\hline Group & $\begin{array}{c}\text { Number } \\
\text { of strain }\end{array}$ & C14:1 & C14:0 & C16:1 & C16:0 & C18:1 & C18:0 & $\triangle 19$ & C20:1 & \%Unknown \\
\hline I & 4 & 3.7 & 7.4 & 6.4 & 13.2 & 27.8 & 6.2 & 7.3 & 11.6 & 16.3 \\
II & 6 & 3.8 & 7.8 & 8.2 & 14.0 & 41.7 & 3.7 & 3.5 & 5.7 & 11.6 \\
ATCC 33315 & & 2.5 & 5.1 & 2.5 & 12.9 & 10.9 & 10.6 & 12.6 & 20.5 & 22.3 \\
JCM 10006 & & 5.1 & 6.0 & 3.1 & 13.4 & 11.0 & 10.2 & 11.1 & 19.2 & 20.7 \\
III & 2 & 4.0 & 17.5 & 5.6 & 14.9 & 38.9 & 1.4 & - & 2.5 & 15.4 \\
A. viridans * & & 5.0 & 8.0 & 31.0 & 20.0 & 22.0 & 2.0 & - & 7.0 & 4.0 \\
\hline
\end{tabular}

${ }^{*}$ Data from O, Leary and Wikinson $(1988) ; \triangle$, Cyclopropane acid

Table 4. DNA relatedness of Tetragenococcus strains

\begin{tabular}{|c|c|c|c|c|c|}
\hline \multirow{2}{*}{ Group } & \multirow{2}{*}{$\begin{array}{l}\text { Number of } \\
\text { Strain }\end{array}$} & \multicolumn{4}{|c|}{ \% Homology with labeled strains } \\
\hline & & ATCC $33315^{\mathrm{r}}$ & JCM10006 $6^{\prime \prime}$ & K3-26 & TISTR $393^{\prime \prime}$ \\
\hline I & 40 & $70.0-109.1$ & $4.7-64.8$ & $5.9-51.8$ & $\mathrm{ND}$ \\
\hline \multirow[t]{2}{*}{ II } & 38 & $8.8-63.6$ & $70.9-105.6$ & $71.5-107.5$ & ND \\
\hline & K3-26 & 24.9 & 89.5 & 100.0 & ND \\
\hline III & 2 & $23.7-3.9$ & $3.8-4.1$ & $4.0-4.9$ & $12.3-16.3$ \\
\hline T.halophilus & ATCC $33315^{1 \prime}$ & 100.0 & 16.7 & 24.1 & ND \\
\hline T. muriaticus & JCM $10006^{\mathrm{T}}$ & 26.0 & 100.0 & 106.6 & ND \\
\hline A.viridans & TISTR $393^{\mathrm{r}}$ & ND & ND & ND & 100.0 \\
\hline
\end{tabular}

ND, not determined 
7) Anonymous.: Validation of the publication of new names and new combinations previously effectively published outside the IJSB. List no.49. Int. J. Syst. Bacteriol., 44, 370-371 (1994).

8) Villar, M., Holgado, A. P., Sanchez, J. J., Trucco, R. E., and Oliver, G.: Isolation and characterization of Pediococcus halophilus from salted anchovies (Engraulis anchoila). Appl. Environ. Microbiol., 49, 664-666 (1985).

9) Roling, W. F. M. and Verseveld, H. W. V.: Characterization of Tetragenococcus halophila populations in Indonesian soy mash (kecap) fermentation. Appl. Environ. Microbiol., 62, 1203-1207 (1996).

10) Collins, M.D., Wiliam, A.M., and Wallbanks, S.: The phylogeny of Aerococcus and Pediococcus as determined by $16 \mathrm{~S}$ rRNA sequence analysis: description of Telragenococcus gen. nov. FEMS Microbiol Letl., 70, 255-262 (1990).

11) Satomi, M., Kimura, B., Mizoi, M., Sato, T., and Fujii, T.: Tetragenococcus muriaticus sp. nov., a new moderately halophilic lactic acid bacterium isolated from fermented squid liver sauce. Int. J. Syst. Bacteriol., 47, 832-836 (1997).

12) Kobayashi, T., Kimura, B., and Fujii, T.: Differentiation of Tetragenococcus populations occuring in products and manufacturing processes of puffer fish ovaries fermented with rice-bran. Int. J. Food. Microbiol., 56, 211-218 (2000).

13) Saisithi, P., Kasemsarn, B, Liston, J.J., and Dollar, A. M.: Microbiology and chemistry of fermented fish . J. Food Sci., 31, 105-110 (1966).

14) Beddows, C.G.: Fermented fish and fish products. In "Microbiology of fermented foods", Vol. 1, ed. Wood, B.J.B., Blackie Academic \& Professional, New York, pp. 416-429 (1998).

15) Tanasupawat, S. and Komagata, K.: Lactic acid bacteria in fermented foods in Thailand. World $J$. of Microbiol \& Biotechnol., 11, 253-256 (1995).

16) De Man, J. C., Rogosa, M., and Sharpe, M. E.: A medium for the cultivation of lactobacilli. J. Appl. Bacteriol., 23, 130-135 (1960).

17) Hucker, G. J. and Conn, H. J., Method of gram staining. Technical Bulletin 93, New York State Agricultural Experiment Station, Ithaca, pp.3-37 (1923).

18) Whittenbury, H.: The use of soft agar in the study of conditions affecting the utilization of fermentable substrates by lactic acid bacteria. J. Gen. Microbiol., 32, 375-384 (1963).

19) Barrow, G. I. and Feltham, R. K. A.: Cowan and Steel's manual for the Identification of medical bacteria, Cambridge University Press, Cambridge (1993).

20) Tanasupawat, S., Ezaki, T., Suzuki, K., Okada, S., Komagata, K., and Kozaki, M.: Characterization and identification of Lactobacillus penlosus and Lactobacillus plantarum strains from fermented foods in Thailand. J. Gen. Appl. Microbiol., 38, 121134 (1992).

21) Tanasupawat, S., Okada, S., and Komagata, K.,
Lactic acid bacteria found in fermented fish in Thailand. J. Gen. Appl. Microbiol., 44, 193-200 (1998).

22) AOAC Methods.: Fish and other marine products, Histaminc. in "Seafood", (Fifteenth Ed.), Chapter 35, pp. 876-877 (1990).

23) Okada, S., T. Toyoda and M. Kozaki.: An easy method for the determination of the optical types of lactic acid produced by lactic acid bacteria . Agric. Biol. Chem., 42, 1781-1783 (1978).

24) Ikemoto, S., Katoh, K., Komagata, K., Cellular fatty acid composition in methanol-utilizing bacteria. J. Gen. Appl. Microbiol., 24, 41-49 (1978).

25) Saito, H. and Miura, K.: Preparation of transforming deoxyribonucleic acid by phenol trealment. Biochim, Biophys. Acta., 72, 619-629 (1963).

26) Yamada, K. and Komagata, K., Taxonomic studies on conryneform bacteria. III. DNA base composition of coryneform bacteria. J. Gen. Appl. Microbiol., 16, 215- 224 (1970).

27) Ezaki,T., Hashimoto,Y., and Yabuuchi, E.: Fluorometric deoxyribonucleic acid deoxyribonucleic acid hybridization in microdilution wells as an alternative to membrane filter hybridization in which radioisotopes are used to determine genetic relatedness among bacterial strains. Int. J. Syst. Bacteriol., 39, 224-229 (1989).

28) Tanasupawat, S., Shida, O., Okada, S., and Komagata, K.: Lactobacillus acidipiscis sp.nov. and Weissella thailandensis sp. nov., isolated from fermented fish in Thailand. Int. J. Syst. Evol. Microbiol., 50, 1479-1485 (2000).

29) Dellaglio, F., Trovatelli, L. D. and Sarra, P. G.: DNA-DNA homology among representative strains of the genus Pediococcus. Zbl. Bakt. Hyg., I. Abt. Orig., 2, 140-150 (1981).

30) Garvie, E. I., Genus Pediococcus. In Bergey 's Manual of Systematic Bacteriology, Vol. 2, eds. Sneath, P.H.A., Mair, N.S., Sharpe, M. E. and Holt., J.G., The Williams \& Wilkins, Baltimore, pp. 1075-1079 (1986).

31) Wayne, G., Brenner, D. J., Colwell, R. R., Grimont, P. A. D., Kandler, O., Krichevsky, M. J., Moore, L. H., Moore, W. E. C., Murry, R. G. E., Stackebrandt, E., Starr, M. P. and Truper, H. G.: Report of the Ad Hoc committee on reconciliation of approaches to bacterial systematics. Int. J. Syst. Bacteriol., 37, 463-464 (1987).

32) Weiss, N.: The genera Pediococcus and Aerococcus. In The Prokaryotes, Vol.1, eds. Balows, A., Truper, H. G., Dworkin, M., Harder, W., and Schleifer, K. H., Springer-Verlag, New York, pp. 1502-1504 (1992).

33) Uchida, K. and Mogi, K.: Cellular fatty acid spectra of Pediococcus species in relation to their taxonomy. J. Gen. Appl. Microbiol., 18, 109-129 (1972).

34) O'Leary, W. M. and Wikinson, S.G.: Gram-positive bacteria . In Microbial Lipid,Vol.1, eds. Ratledge C. and Wikinson, S. G., Academic Press, London, pp. 117-201(1988). 